\title{
The evolution of saltmarsh mosquito control water management practices relative to coastal resiliency in the Mid-Atlantic and northeastern United States
}

\author{
Roger Wolfe (iD) Paul Zarebicki · William Meredith
}

Received: 16 March 2021 / Accepted: 2 July 2021 / Published online: 13 August 2021

(C) The Author(s) 2021

\begin{abstract}
Salt marshes are dynamic ecosystems that change in response to local geographic and geologic factors as well as sea level changes. Most east coast salt marshes are the result of rising sea levels since the end of the last ice age, about 20,000 ybp. To compound this natural process, anthropogenic manipulations for farming, development and other purposes have occurred for centuries. Alterations to salt marshes for the purpose of controlling larval mosquitoes at their source, at least along the east coast of the United States, have occurred since the early twentieth century. These alterations have included large-scale manipulations such as extensive parallel grid-ditching and impounding. Within the last 50 years, more selective source reduction methods such as Open
\end{abstract}

\section{R. Wolfe $(\bowtie)$}

Connecticut Wildlife Division, Wetland Habitat and Mosquito Management Program, Department of Energy and Environmental Protection, 391 Rt. 32, N. Franklin, CT 06254, USA

e-mail: roger.wolfe@ct.gov

\section{P. Zarebicki}

Delaware Mosquito Control Section, Division of Fish \& Wildlife, Department of Natural Resources and Environmental Control, 1161 Airport Rd., Milford, DE 19963, USA

\section{W. Meredith}

Delaware Mosquito Control Section, Division of Fish \& Wildlife, Department of Natural Resources and Environmental Control, 89 Kings Highway, Dover, DE 19901, USA
Marsh Water Management (OMWM) have been employed with fewer deleterious impacts to marsh resources. Even more recently, the more holistic approach of Integrated Marsh Management (IMM) has been used with considerable success particularly in the northeastern and Mid-Atlantic states. IMM not only uses OMWM techniques but incorporates the judicious use of mosquito control pesticides, tidal flow restoration, impoundment management, wildlife habitat enhancement, invasive plant control, and selective shallow ditching ("runneling") depending on local conditions and management plans. As many marshes are becoming wetter and either drowning or migrating inland (where possible) due to the effects of increasing rates of sea level rise, the compounding long-term impacts of parallel grid-ditching and past manipulations on marsh surface elevation and hydrology are being more intently studied. These changes in saltmarsh dynamics have had and will continue to have impacts on where saltmarsh mosquitoes are produced, which could have corollary effects on public health and quality of life near coastal communities. As salt marshes continue to change, mosquito control agencies can play a significant role in providing input for salt marsh restoration and management in addition to their primary objective of vector control and enhancing quality of life. 
Keywords Salt marsh - Mosquito control - Open Marsh Water Management · Integrated Marsh Management

\section{Introduction}

Tidal salt marshes are coastal marshes influenced by ocean tides and are some of the most ecologically important (in terms of primary productivity) ecosystems in the world. In very general terms salt marshes can be divided into two main zones. The low marsh area is regularly influenced by daily tides whereas the high marsh is only flooded by rain, spring tides, or storm-driven tidal events. It is the high marsh that is typically of greatest concern for saltmarsh mosquito production, as the more frequently flooded low marsh is generally too wet for saltmarsh mosquito egg deposition and incubation. Salt marshes can be further classified by their level of salt content ranging from tidal freshwater $(<0.5 \mathrm{ppt})$, to oligohaline $(0.5-5 \mathrm{ppt})$, to mesohaline (5-18 ppt), to polyhaline (18-30 ppt), to marine or euhaline (>30 ppt) (Mitsch and Gosselink 2000).

As implied, saltmarsh mosquitoes can tolerate high levels of salt water. In general terms, there are two main "types" of mosquitoes that occur in salt marshes, often called "floodwater" and "standing water" mosquitoes. Floodwater mosquito species lay their eggs on moist mud or other substrates where they require a non-immersed incubation period before being flooded by spring/storm tides or heavy rainfall. These moist mud depressions or "potholes" are most commonly found in the high marsh, dominated by salt hay grasses such as Spartina patens, Distichlis spicata and Juncus gerardii. On the east coast of North America, the three primary floodwater saltmarsh mosquito species are Ochlerotatus cantator (brown saltmarsh mosquito), O. sollicitans (eastern saltmarsh mosquito), and $O$. taeniorhynchus (black saltmarsh mosquito). Ochlerotatus cantator is most common in Northeast salt marshes, $O$. sollicitans dominates the Mid-Atlantic salt marsh, while O. taeniorhynchus is the dominant floodwater species of the South Atlantic and Gulf Coasts, although their ranges overlap in areas and also show local seasonal abundance trends. On the Pacific Coast, Ochlerotatus dorsalis (summer saltmarsh mosquito) is the dominant saltmarsh species.
These species can be prolific breeders, aggressive mammal biters and strong fliers capable of flying several miles in search of a blood meal (Carpenter and LaCasse 1955). In the Northeast, Ochlerotatus cantator tends to emerge earlier in the summer and can be a provisional nuisance but its numbers are quickly overwhelmed by $O$. sollicitans. All four species are capable of carrying West Nile virus (WNV) but are not considered major vectors of this pathogen. Ochlerotatus sollicitans, O. cantator, and O. taeniorhynchus can be vectors of eastern equine encephalitis (EEE) and dog heartworm (filariasis), while $O$. dorsalis can carry western equine encephalitis virus (WEE), St. Louis encephalitis virus (SLE), and California encephalitis virus (CEV) (Darsie and Ward 2005).

Conversely, standing water mosquitoes lay their eggs (either individually or clustered in egg rafts) directly onto the surface of semi-permanent or permanent fresh or salt water. Along Atlantic Coast salt marshes, the main standing water mosquito species are Culex salinarius (unbanded saltmarsh mosquito) and Anopheles bradleyi. Culex salinarius is an important bridge vector of WNV (Andreadis et al. 2004), while An. bradleyi can also vector EEE (Darsie and Ward 2005).

As noted, saltmarsh mosquitoes are very prolific breeders and strong fliers. At least on the Atlantic and Gulf Coasts, most modern-day mosquito control programs were initially created because of the swarms of mosquitoes that emerge from salt marshes. Furthermore, their aggressive behavior, vector potential, effect on public health, adverse impact on quality-oflife, and negative effect on local economies necessitate control in populated areas (Rochlin et al. 2012).

\section{Early mosquito control in coastal marshes}

Native Americans utilized the bounty that coastal marshes and estuaries offered but it was not until the colonial period that human activity had a more direct impact to those salt marshes. In the modern era, proximity to heavily populated areas in the eastern United States, where $75 \%$ of the population lives within $100 \mathrm{~km}$ of the coast (Chambers et al. 1999) has led to severe tidal wetland loss (up to $\sim 50 \%$ in some states) due to urbanization that, via filling, obliterates wetlands (Bromberg and Bertness 2005). Those that remain have had further negative impacts upon them 
through farming, myriad types of hydrologic manipulations, and mosquito control practices since the early twentieth century. By the 1930's, $90 \%$ of saltmarshes from Maine to Virginia were parallel grid-ditched for mosquito control (Bourn and Cottom 1950). Perhaps a heavy-handed approach for controlling mosquitoes, this method was used extensively throughout New England, the Mid-Atlantic, and to a lesser extent elsewhere, as a means of employing workers following the Great Depression through the formation of the Civilian Conservation Corps (CCC). However, the concept of ditching was not without merit. As early as the turn of the twentieth century, Smith (1902) observed that the high marsh contained the prime mosquito-breeding areas and ditching aided to drain them and lessen mosquito production by dewatering the semi-permanent pools. Ditches can also help provide access for native larvivorous marsh killifish which can be an effective biological control agent. Smith further advocated (1907) that more permanent improvements (i.e., water management) should be the objective as opposed to the application of surface oil, which is a temporary expedient of a rather harsh nature. During the early part of the twentieth century, agricultural pesticides such as Paris Green and organochlorine insecticides were also applied to the marshes. In many cases, these did provide effective control of mosquito larvae but also resulted in deleterious impacts to many non-target organisms thus giving further evidence for support of the use of physical manipulations like water management.

Throughout the first half of the twentieth century, other attempts at controlling saltmarsh mosquitoes through water management took place including dynamiting ponds, digging blind ditches to harbor killifish, creating impoundments to control water levels, and other methods (Dale and Hulsman 1990; Wolfe 1996). Open Marsh Water Management (OMWM) was developed in New Jersey in the mid1960's (Ferrigno and Jobbins 1968) as a management technique for controlling saltmarsh mosquitoes using physical alterations of marsh habitat. Using this method, ponds and ditches are selectively excavated in mosquito-breeding areas (Fig. 1) in order to create unsuitable environs for mosquito eggs and larvae while creating suitable habitat for larvivorous fish species (Meredith et al. 1985). Similar in its site selectivity and objective, runneling (Hulsman et al. 1989) involves the excavation of shallow $\left(6^{\prime \prime}-8^{\prime \prime}\right)$ channels to allow tidal flushing of mosquito-breeding depressions.

As a more long-lasting and ecologically-sound alternative to temporary chemical control or indiscriminate mechanical drainage (i.e., parallel gridditching), OMWM and runneling promote targeted source reduction and biological control. The efficacy of both techniques as a control agent, and impacts to vegetation and non-target organisms have been reviewed (Dale and Hulsman 1990; Wolfe 1996; Dale and Knight 2008; Dale and Knight 2012; James-Pirri et al. 2011). Another major benefit of such water management techniques is a reduction in need for larvicide treatments due to the source reduction control effects and enhanced fish access (Meredith and Lesser 2007). In terms of lessening non-target impacts from chemical exposures, this certainly was beneficial in an era when relatively harsh chlorinated hydrocarbons or organophosphates were the primary saltmarsh larvicides. The use of OMWM still continues to lower the need to apply the more benign modern larvicides used today. Furthermore, because of OMWM's long-term control, economic advantages are also realized (Wolfe 1996) since continual larvicide treatments are no longer needed over the life of the system.

Over the next three decades OMWM use expanded throughout the Mid-Atlantic and southern New England states. It was anticipated that these systems would last 15 to 20 years before maintenance would be required to preserve their integrity and sustain larvivorous fish access (Meredith et al. 1985). This is significantly less than what was projected on Fire Island (NY) marshes where, with an average sedimentation rate of $0.52 \mathrm{~cm} \mathrm{year}^{-1}$ in open parallel gridditches (but could be as much as $0.85 \mathrm{~cm}_{\text {year }}^{-1}$ in plugged or closed ditches), it could take 74-175 years to fill in naturally (Corman et al. 2012). The need for maintenance may not only be dependent on the marsh as a whole, but also on the location of each OMWM system within a particular marsh landscape. The timing for any necessary maintenance could also be affected by storm surge, deposition of wrack and debris, and soil type. Shallower sills and runnels for example, especially if cut through organic soils, may start to revegetate with Spartina alterniflora (smooth cordgrass) in less than 10 years ( $\mathrm{R}$ Wolfe, pers. observ.) however, systems with deeper $\left(24^{\prime \prime}-36^{\prime \prime}\right)$ lateral channels and ponds, and in more mineral soils have been 


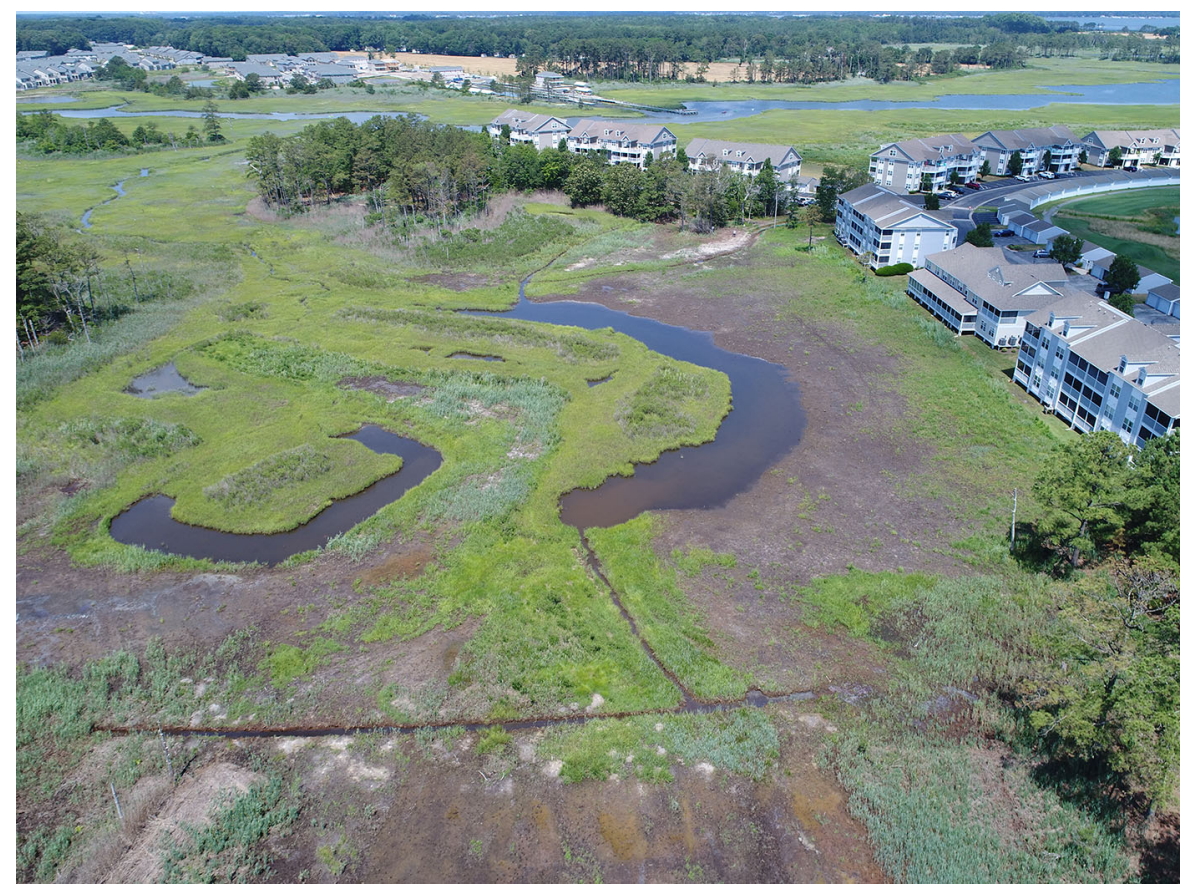

Fig. 1 Newly completed OMWM system near residential area

observed (at least in Delaware and Connecticut) to still be functioning after 30 years (Zarebicki and Wolfe pers. observ.). Once vegetation becomes established, sediment accumulation increases rapidly, and the shallower sills and runnels become occluded. Mosquito control programs in the Mid-Atlantic, New York and New England that have a history of using OMWM, may now spend a portion of their time maintaining previously installed OMWM systems in order to maintain their integrity, in addition to installing new systems where shifts in larval habitat may be occurring due to increased rates of sea level rise.

As effective as OMWM can be for long-term source reduction and biological control, it may not be suitable or practical for all situations. True with controlling any pest, there is no "silver bullet" for saltmarsh mosquito control. Therefore, an Integrated Pest Management (IPM) approach is needed and has been used successfully by progressive Mosquito Control Organizations (MCO) for decades. In fact, because of the specificity of techniques used in mosquito control compared to other forms of pest management, the term Integrated Mosquito Management (IMM) has been coined (Rupp 2001, AMCA 2009). In areas where water management may not be suitable for any number of reasons, the judicious use of approved mosquito- targeting insecticides in the form of larvicides and pupacides is needed to control mosquito larvae and pupae at their source. When used as part of an Integrated Mosquito Management approach including OMWM, the United States EPA and CDC approve the strategic use of registered larvicides (EPA 2012). Most commercially available products today contain either the biological agents Bti (Bacillus thuringiensis var. israelensis) or Bs (Bacillus sphaericus), the insect growth regulators methoprene and pyroproxifen, or smothering agents (i.e., surface oils and monomolecular films). If tides, weather conditions or other factors prohibit an effective application of larvicides, MCO's may have to resort to applying ground or aeriallyapplied Ultra Low Volume (ULV) adulticides to reduce resultant adult mosquito populations. Furthermore, if a mosquito-borne pathogen is detected through surveillance and testing of adult mosquito populations, adulticiding may be the only option to reduce the public health threat of vector mosquitoes. To complement an effective community-wide mosquito control program, a focused public education campaign is also needed to encourage eliminating sources of mosquito breeding around the home, use personal protective measures to prevent or lessen mosquito bites, and support state and local MCO's. 


\section{From OMWM to IMM}

In addition to OMWM's primary goal of source reduction and biological control, secondary benefits could also be achieved in a more Integrated Marsh Management approach (Meredith et al. 1985, Rozsa 1995). Over time, an issue of semantics arose where the use of the term OMWM was being misinterpreted to include activities other than the practice's original intent (Wolfe 2005). Not to be confused with Integrated Mosquito Management, the term Integrated Marsh Management (also IMM) was promoted as a more holistic approach to coastal wetland management and is becoming more widely accepted (Wolfe and Capotosto 1998; Rochlin et al. 2012). The use of a broader term allows for the combination of various techniques and elements to be used to achieve sitespecific goals. Integrated Marsh Management not only incorporates the essentials of OMWM and mosquito pesticide use but, where applicable, encourages activities such as tidal flow restoration through replacement (or outright removal where feasible) of undersized culverts which restrict tidal flow, manipulation of water levels via water control structures for multiple benefits, breaching of impoundment dams, removal of fill to restore marsh elevation and hydrology, cessation of parallel grid-ditch maintenance thereby allowing some ditches (not needed to accomplish other management objectives) to fill in naturally, invasive plant (e.g., Phragmites) control, wildlife habitat enhancement, and education of stakeholders and the general public. Some of the projects can be relatively simple to implement, such as selective recleaning of ditches to restore tidal flushing, or very elaborate, thus requiring engineering, contractual and financial assistance.

Analogous to OMWM in objective and implementation, runneling was developed to provide shallow tidal flushing and fish access to control Aedes vigilax in salt marshes in Australia (Hulsman et al. 1989; Dale et al. 1993). Similarly, recirculation ditches were created in San Francisco Bay marshes to perform the same function (Resh and Balling 1983). By definition, a runnel is a rivulet or small stream (https://www. merriam-webster.com). This technique was first cited in the literature as a source reduction method for mosquito control. More recently, the runneling technique has been used to drain shallow sheet water from saltmarshes in New England (Raposa et al. 2019, Graca and Goldstone 2020). In these instances, mosquito control was not the primary objective although there may have been some ancillary effect. In Connecticut, runnels were used to cut through the parallel grid-ditch levees that build up over time due to maintenance and side-casting of ditch spoils (Fig. 2). These artificial levees (coupled with increasing rates of sea level rise) can trap water and drown the marsh vegetation within, creating unvegetated pannes (Fig. 3). By cutting through these ditch-side levees and allowing drainage of these shallow pannes, vegetative recovery occurred within 8 years (Wolfe unpubl, Fig. 4), whereas Raposa et al (2019) demonstrated that full vegetative recovery of bare soil occurred within 3 years.

Following the era of parallel grid-ditching, there was a general sense that the adverse impacts of ditching and draining tidal wetlands outweighed the ecological and socioeconomic benefits. With the passage of the Federal Coastal Zone Management Act in 1972, states now had the authority to regulate activities in tidal wetlands. For the next few decades, the management of saltmarshes was under considerable regulatory scrutiny to activities such as excavation or placement of excavated material on the marsh surface. However, over the last 20 years the pendulum has started swinging the other way and there is renewed interest in actively managing saltmarshes due primarily to impacts from climate change and its resulting increased rate of sea level rise. OMWM guidelines allow for the spreading of excavated material on the marsh surface (ideally as a crude slurry, see Fig. 5) but the goal is to do so in a manner that will not result in a change in vegetation, either through spoil deposition or drainage from ditching (Meredith et al. 1985). Now because of increasing rates of sea level rise or other factors, some marshes are getting wetter and undergoing a conversion from high marsh to low marsh to eventual mud flat or open water. Thin layer deposition or disposal of dredged materials has been used to raise the marsh platform to encourage plant growth and restore low marsh and high marsh habitats (Ford et al. 1999). Conversely, runneling can be used to effectively drain the standing water to allow vegetative recovery without excessively dewatering the marsh.

Increased risk of flooding, habitat loss of marshdependent species (e.g., Black rail [Laterallus jamaicensis] or Saltmarsh sparrow [Ammodramus caudacutus]), and carbon sequestration are but some 


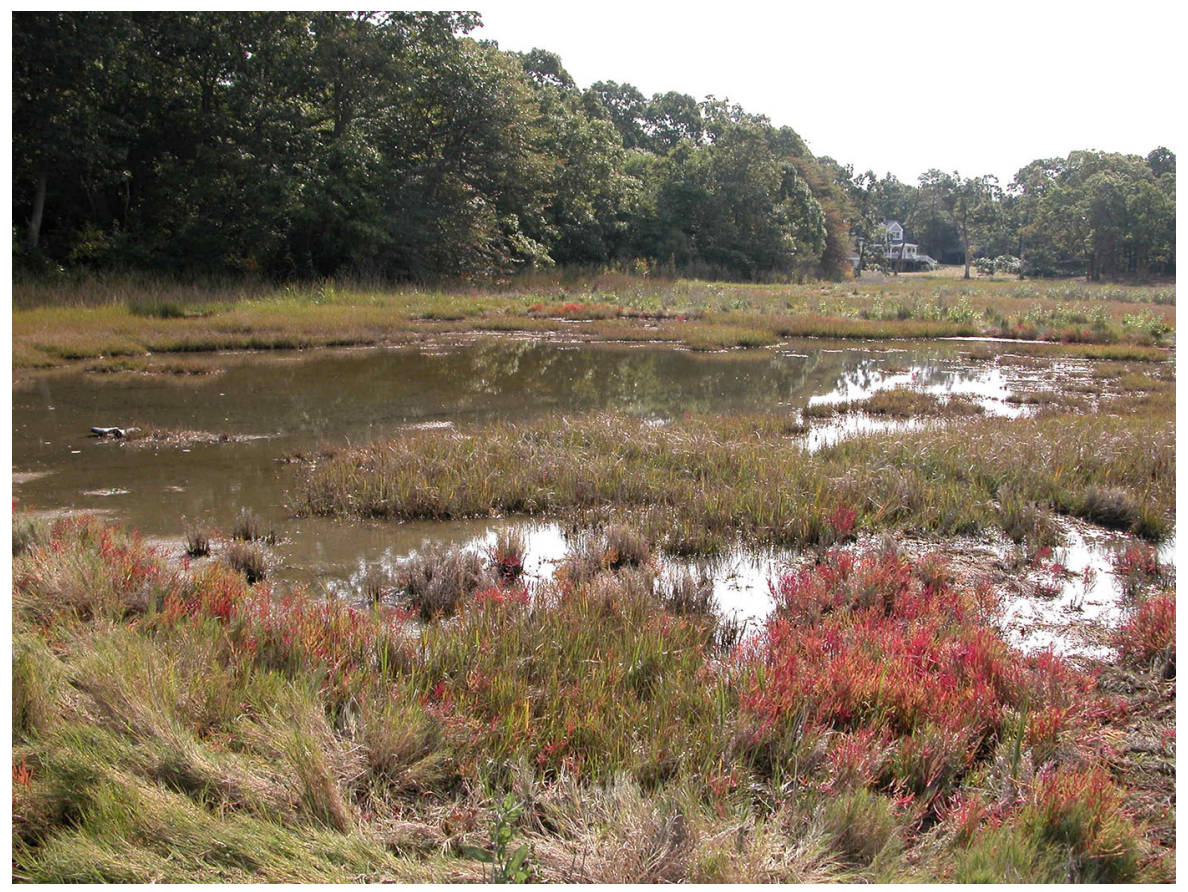

Fig. 2 Ditch maintenance levee creates unvegetated panel

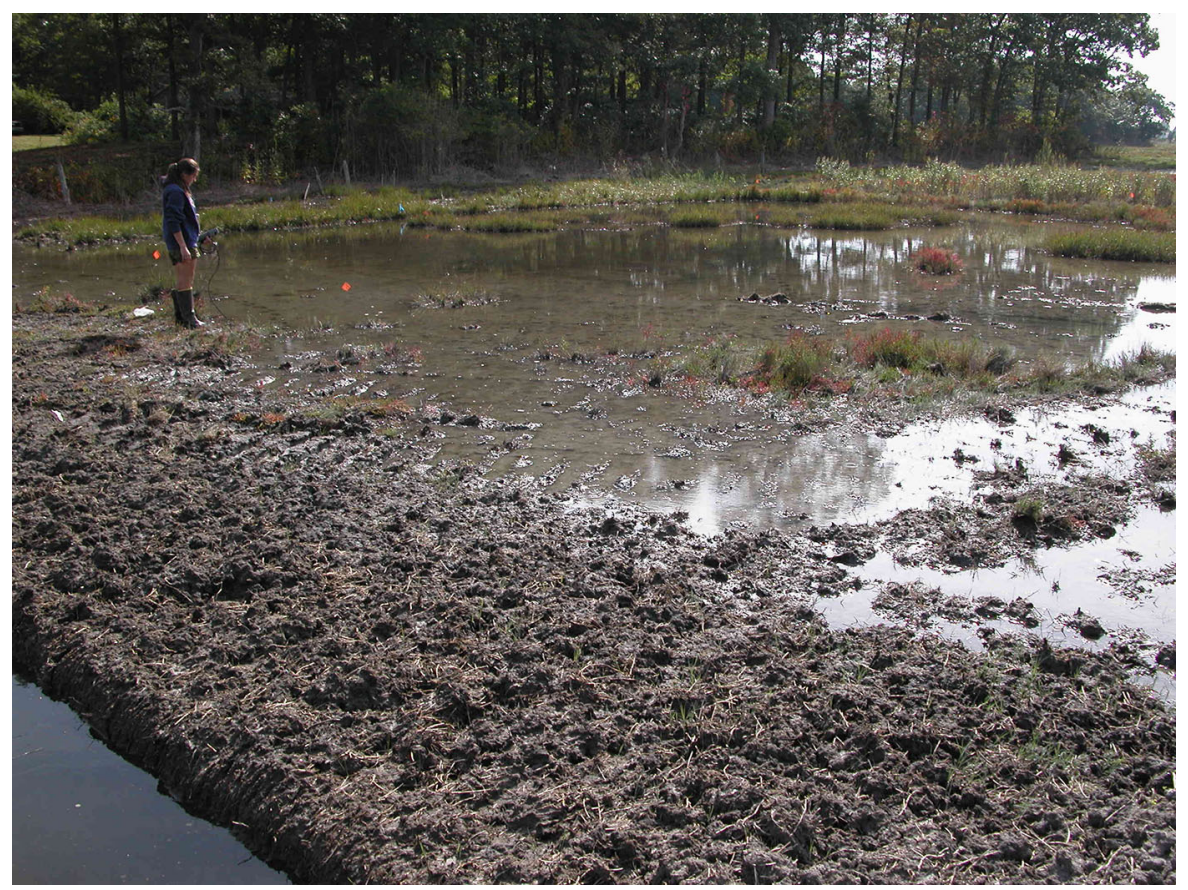

Fig. 3 Runnels are used to cut through ditch levee

of the concerns of scientists and coastal communities. Much emphases have been placed on addressing coastal resiliency, predicting loss and landward migration of tidal wetlands, and a relatively rapid conversion of vegetated marsh to mud flat. Such conversion could have significant impacts on habitat 


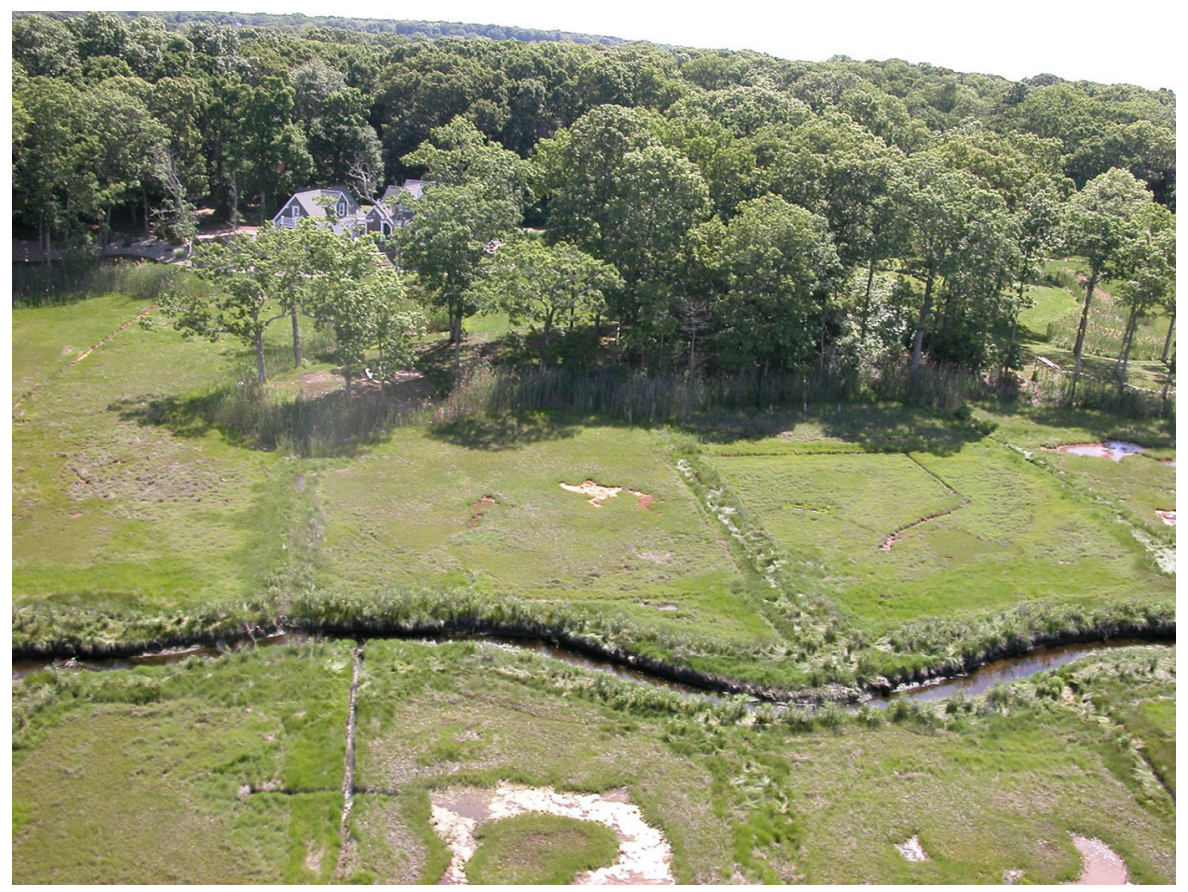

Fig. 4 Runnels allowed revegetation within 8 years in CT

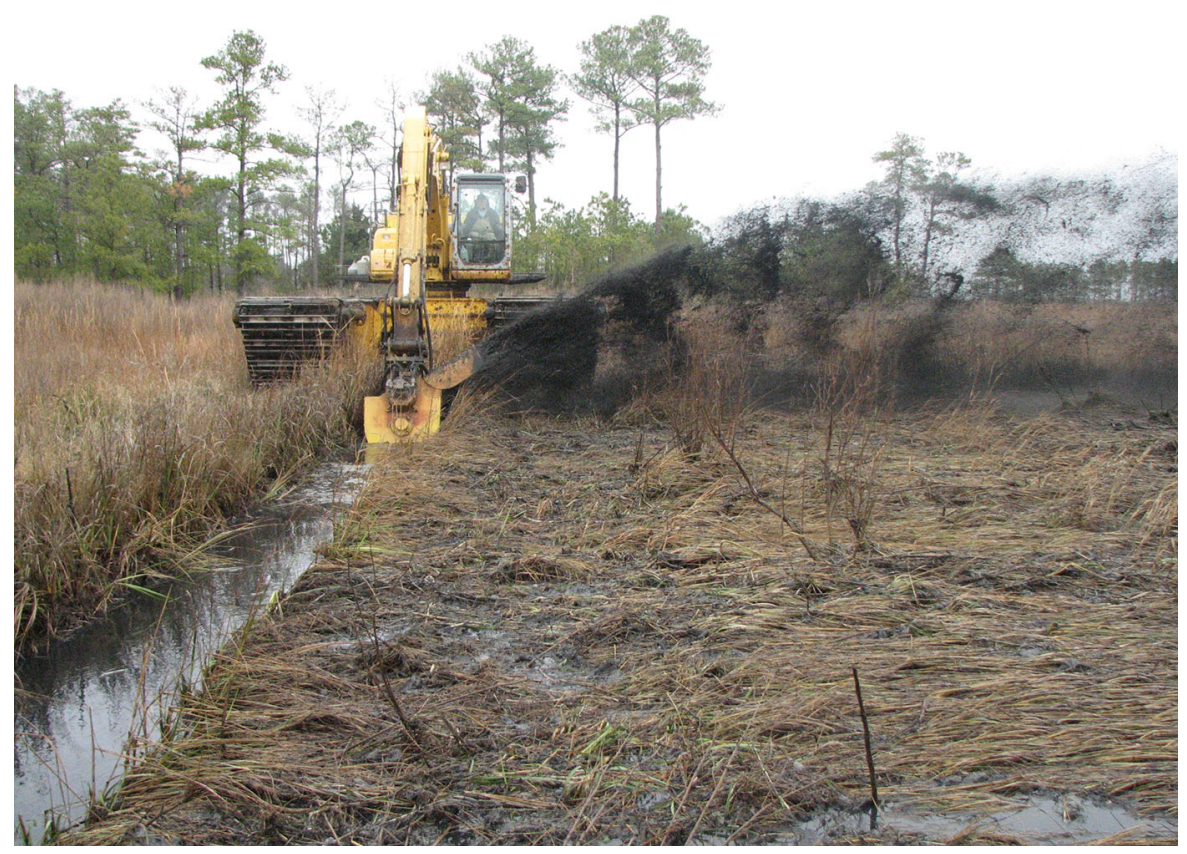

Fig. 5 A rotary excavator spreads spoil as a slurry

loss for several high marsh dependent species and on mosquito production. Various management interventions are now needed in many locations to help slow or counter these losses or degradations. The irony is that, once considered ominous and foreboding, drainage of shallow surface water through runneling and filling 
marshes through placement of spoil are now not only allowed but encouraged in many areas to offset the drowning of marshes. As projects involving these methods are in their relative infancy, they are cautiously being regulated, monitored and studied for effectiveness and long-term impacts. Still, they show promise as tools in an Integrated Marsh Management toolbox and as such we have added them to the schematic that Rochlin et al. (2012) presented (Fig. 6). However, these techniques have to be implemented with care and well monitored to allow for any necessary adaptive management. For example, OMWM alterations can help reduce saltmarsh mosquito production and the need for larvicide applications and also restore valuable surface water features for fish and wildlife to previously parallel grid-ditched marsh. However in terms of other effects, Elsey-Quirk and Adamowicz (2015) indicate that OMWM ponding-and-ditching through changes in the extent of emergent vegetation cover vs. ponded water surface, changes in surface elevation due to thin-layer disposal of OMWM-generated material, and changes in local accretion and deposition rates for tidally-borne sediments might either adversely exacerbate or helpfully slow down marsh topography changes in the face of rising sea levels. These types of changes might help increase marsh surface resiliency to sea level rise or conversely, possibly accelerate marsh surface fragmentation caused by sea level rise which can vary not only among different marshes but also at various locations within a single marsh.

\section{Need for continual involvement}

With increased interest surrounding climate change and sea-level rise, intuitively one would think that a gradual conversion of high, irregularly-flooded marsh to low, more regularly-flooded marsh would mean less habitat for saltmarsh mosquito egg deposition. This is yet to be quantified, however, mosquito control practitioners who have a familiarity with their coastal areas over the course of a few decades have become aware of sections of the upland/high marsh interface that now produce mosquitoes more frequently than they may have in the past (Zarebicki pers. observ.). If marshes are allowed to migrate inland and the topography allows for such, there is potential for the creation of new irregularly-flooded high marsh and therefore new mosquito production areas. Mosquito control agencies need to be aware of this and work with government and academic scientists modeling the effects of sea level rise and coastal changes to monitor for newly emerging mosquito production
Fig. 6 Revised Integrated Marsh Management schematic

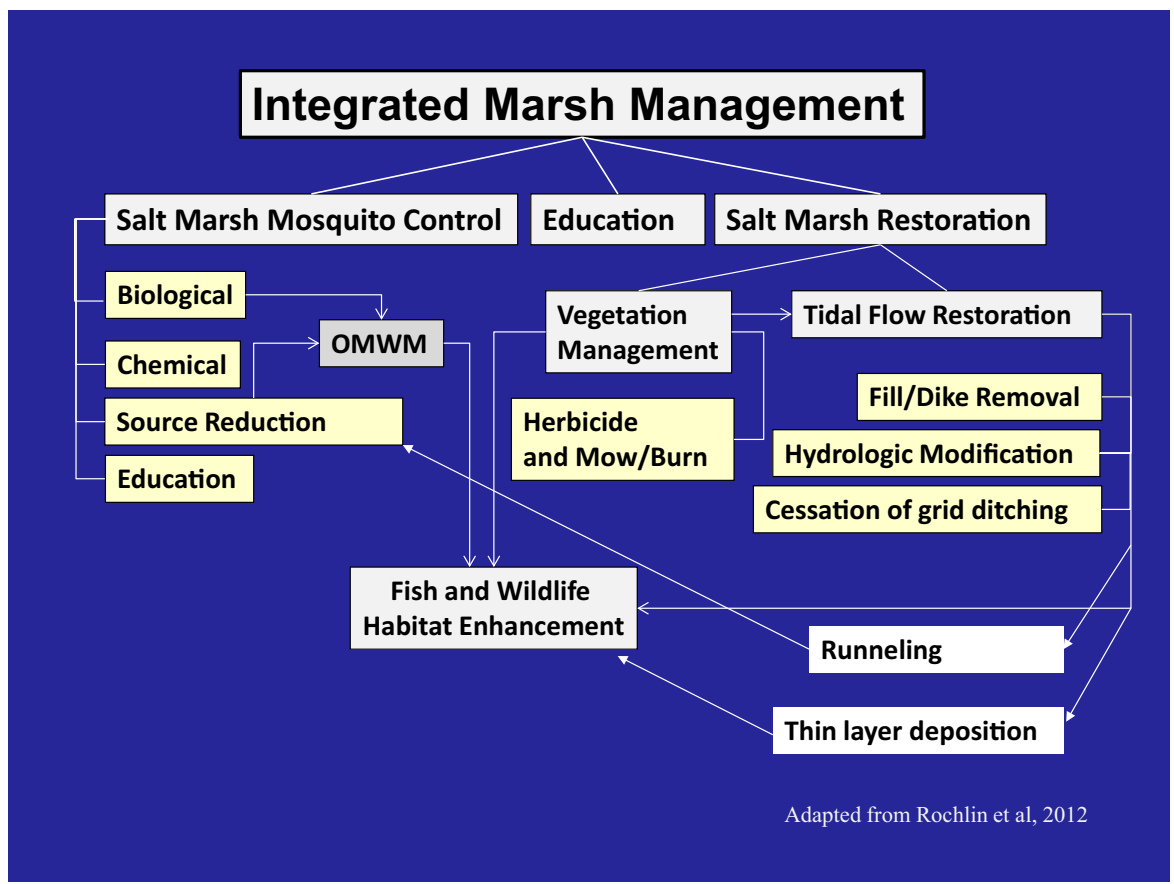


areas, whether it be irregularly-flooded areas or creation of new depression sites ("potholes"), both being habitats conducive for Ochlerototus production, or standing water areas that may be attractive to Culex or Anopheles species.

Many of these resiliency projects are in their infancy and long-term monitoring plans may include vegetation recovery, water quality (including management of acid sulfides), or bird, fish, and invertebrate use. It may take several years for these sites to become attractive oviposition sites for saltmarsh mosquitoes, yet monitoring for this should still be conducted. It is well known in the mosquito control arena that areas impounded for the purpose of containing dredged sediments can be prolific sources of mosquito egg deposition, once the silty deposits dry out, crack, and lead to deep fissures. Although perhaps not as deep (because the deposited sediments are not as thick), similar cracks and fissures may occur at thin layer deposition sites if similar silty soils are used. Also, sediment deposits must be spread and graded in a manner that will not block surface water from exiting the marsh surface. Care must be taken in the placement of excavated materials to allow for adequate surface drainage, encourage vegetative recovery, and to prevent pooling of surface water.

\section{Conclusion}

There is renewed interest in salt marsh management and coastal resiliency as a result of increased rates of sea level rise and continued anthropogenic impacts. Coastal regulators, researchers, and managers are contending with ways to lessen, if not reverse, the impacts caused by sea level rise and other factors. In addition, coastal mosquito control programs also have a continued responsibility for providing public health services by keeping abreast of these ongoing efforts to assist in monitoring restored areas. With such a varied group of interests and stakeholders, it is vital that coastal MCO's be engaged with other governmental, non-governmental, and academic groups (and vice versa) in order to share views, goals and expertise. MCO's should be involved in projects from the onset so that inadvertent creation of mosquito production areas can be circumvented. This will prevent or minimize having to revisit restoration sites to address mosquito issues inadvertently created by not taking this into consideration during the planning process. It should be noted that the goals of IMM can be realized in concert with other management goals for salt marshes. It is imperative then that such interdisciplinary teams be created for developing, researching, implementing, regulating and monitoring coastal projects.

In the face of this ever-changing and dynamic saltmarsh landscape, mosquito control agencies can and should continue to play a significant role in providing input for salt marsh restoration and management so that all management goals and interests can be addressed and handled in the most holistic manner possible. Dale and Knight (2008) acknowledge that there needs to be communication and cooperation between mosquito managers and wetland managers to balance the interests of each, especially in the context of changing land use and climate change. Fortunately, much more interaction and collaboration is now occurring among interested parties and this needs to continue and be expanded upon. But there is still an immutable constant that saltmarsh mosquitoes, if left unchecked, can cause myriad problems in populated areas that modern society simply will not tolerate, with the public looking to MCOs to provide a level of relief that people need, expect and demand. The challenge is always to do this in an environmentally compatible manner.

Author contributions All authors whose names appear on the submission have adhered to the authorship principles applicable to our area of expertise.

Funding Authors are state government employees and funding is provided by their respective state agencies.

Open Access This article is licensed under a Creative Commons Attribution 4.0 International License, which permits use, sharing, adaptation, distribution and reproduction in any medium or format, as long as you give appropriate credit to the original author(s) and the source, provide a link to the Creative Commons licence, and indicate if changes were made. The images or other third party material in this article are included in the article's Creative Commons licence, unless indicated otherwise in a credit line to the material. If material is not included in the article's Creative Commons licence and your intended use is not permitted by statutory regulation or exceeds the permitted use, you will need to obtain permission directly from the copyright holder. To view a copy of this licence, visit http://creativecommons.org/licenses/by/4.0/. 
Data availability All data and figures are available upon request.

\section{References}

American Mosquito Control Association (2009) Best practices for integrated mosquito management. Available at http:// www.mosquito.org/assets/Resources/PRTools/Resources/ bmpsformosquitomanagement.pdf

Andreadis TG, Anderson JF, Vossbrinck CR, Main AJ (2004) Epidemiology of West Nile virus in Connecticut: a fiveyear analysis of mosquito data 1999-2003. Vector Borne Zoonotic Dis 4:360-378

Bourn WS, C Cottam (1950) Some biological effects of ditching tidewater marshes. Research Report 19. Fish and Wildlife Service. US Dept of Interior. Washington, DC

Bromberg KD, Bertness MD (2005) Reconstructing New England salt marsh losses using historical maps. Estuaries 28:823-832

Carpenter SJ, La Casse WJ (1955) Mosquitoes of North America, north of Mexico. University of California Press, Berkeley

Chambers RM, Meyerson LA, Saltonstall K (1999) Expansion of Phragmites australis into tidal wetlands of North America. Aquat Bot 64:261-273

Corman SS, CT Roman, JW King, PG Appleby (2012) Salt marsh mosquito-control ditches: sedimentation, landscape change, and restoration implications. J Coastal Res 28:874-880

Dale PER, Hulsman K (1990) A critical review of salt marsh management methods for mosquito control. Crit Rev Aquatic Sci 3:281-311

Dale PER, Knight JM (2008) Wetlands and mosquitoes: a review. Wetlands Ecol Manag 16:255-276

Dale PER, Knight JM (2012) Managing mosquitoes without destroying wetlands: an eastern Australian approach. Wetlands Ecol Manag 20:233-242

Dale PER, Dale PT, Hulsman K, Kay BH (1993) Runnelling to control saltmarsh mosquitoes: long-term efficacy and environmental impacts. J Am Mosq Control Assoc 9:174-181

Darsie RF Jr, Ward RA (2005) Identification and geographical distribution of the mosquitoes of North America, north of Mexico. University Press of Florida, Gainesville

Elsey-Quirk T, Adamowicz SC (2015) Influence of physical manipulations on short-term salt marsh morphodynamics: examples from the North and Mid-Atlantic Coast, USA. Estuaries Coasts 39(2):423-439. https://doi.org/10.1007/ s12237-015-0013-9

Ferrigno F, Jobbins DM (1968) Open marsh water management. Proc NJ Mosq Exterm Assoc 55:104-115

Ford MA, Cahoon DR, Lynch JC (1999) Restoring marsh elevation in a rapidly subsiding salt marsh by thin-layer deposition of dredged material. Ecol Eng 12(3-4):189-205. https://doi.org/10.1016/S0925-8574(98)00061-5

Grace M, Goldstone H (2020) Assessing new salt marsh restoration technique in Buzzards Bay. Available at https:// www.woodwellclimate.org/assessing-new-salt-marshrestoration-technique-in-buzzards-bay/

Hulsman K, Dale PER, Kay BH (1989) The runnelling method of habitat modification: an environment-focused tool for salt marsh mosquito management. J Am Mosq Control Assoc 5:226-234

James-Pirri M-J, Erwin M, Prosser DJ, Taylor JD (2011) Responses of salt marsh ecosystems to mosquito control management practices along the Atlantic Coast (USA). Soc for Eco Rest Inter. https://doi.org/10.1111/j.1526-100X. 2010.00767.x

Joint Statement on Mosquito Control in the United States from the U.S. Environmental Protection Agency (EPA) and the U.S. Centers for Disease Control and Prevention (CDC). (2012) Available at https://www.epa.gov/mosquitocontrol/ joint-statement-mosquito-control-united-states

Meredith WH, Lesser CR (2007) Open marsh water management in Delaware: 1979-2007. Proc NJ Mosq Control Assoc 40:55-69

Meredith WH, Saveikis DE, Stachecki C (1985) Guidelines for "Open Marsh Water Management" in Delaware's salt marshes-objectives, system designs and installation procedures. Wetlands 5:119-133

Mitsch WJ, Gosselink JG (2000) Tidal salt marshes. Wetlands. Wiley, New York, pp 61-305

Raposa KB, Weber RL, Ferguson W, Hollister J, Rozsa R, Maher N, Gettman A (2019) Drainage enhancement effects on a waterlogged Rhode Island (USA) salt marsh. Estuar Coast Shelf Sci. https://doi.org/10.1016/j.ecss.2019.106435,(106435)

Resh VH, Balling SS (1983) Ecological impact of mosquito control recirculation ditches on San Francisco Bay marshlands: study conclusions and management recommendations. Proc Pap Annu Conf Calif Mosq Vector Control Assoc 51:49-53

Rochlin I, James-Pirri MJ, Adamowicz SC, Wolfe RJ, Capotosto P, Dempsey ME, Iwanejko T, Ninivaggi D (2012) Integrated Marsh Management (IMM): a new perspective on mosquito control and best management practices for salt marsh restoration. Wetlands Ecol Manag 20:219-232

Rozsa R (1995) Tidal wetland restoration in Connecticut. In: Dreyer GD, Niering WA (eds) Tidal marshes of Long Island Sound: ecology, history and restoration. Conn Coll Arbor Bull No. 34. Connecticut College, New London, pp 51-65

Rupp HR (2001) Integrated mosquito management: no new thing. Emerg Infect Dis 7(4):761-762

Smith JB (1902) The salt-marsh mosquito Culex sollicitans, Wlk. NJ Agric Exp Stn Spec Bull T, New Brunswick

Smith JB (1907) The New Jersey salt marsh and its improvement. NJ Agric Exp Stn Bull, New Brunswick

Wolfe RJ (1996) Effects of Open Marsh Water Management on selected tidal marsh resources: a review. J Am Mosq Control Assoc 12(4):701-712

Wolfe RJ (2005) Open marsh water management: a review of system designs and installation guidelines for mosquito control and integration in wetland habitat management. Proc NJ Mosq Control Assoc 92:3-14

Wolfe R, Capotosto P (1998) Integrated Marsh Management: a holistic approach to wetlands management in Connecticut. Proceedings Northeastern Mosquito Control Association. Northeastern Mosquito Control Association, Connecticut

Publisher's Note Springer Nature remains neutral with regard to jurisdictional claims in published maps and institutional affiliations. 